\title{
EFFECTIVENESS OF FRANGIPANI LEAF EXTRACT (Plumeria alba LINN.) AS A UV FILTER
} [Uji Efektivitas Ekstrak Daun Kamboja Putih (Plumeria alba Linn.) sebagai UV Filter]

\author{
Irein Kusuma Angreini ${ }^{1}$, Aniek Prasetyaningsih ${ }^{2 * \bowtie}$, Vinsa Cantya Prakasita ${ }^{2}$ \\ ${ }^{1}$ Undergraduate, Faculty of Biotechnology, Duta Wacana University \\ Jl. Dr. Wahidin Sudirohusodo No.5-25, Kotabaru,Gondokusuman, Special Region of Yogyakarta 55224 \\ ${ }^{2}$ Department of Biology, Faculty of Biotechnology, Duta Wacana University \\ Jl. Dr. Wahidin Sudirohusodo No.5-25, Kotabaru,Gondokusuman, Special Region of Yogyakarta 55224 \\ email: aniek@staff.ukdw.ac.id
}

\begin{abstract}
ABSTRAK
Paparan sinar matahari mengandung sinar UV yang berbahaya bagi kulit, untuk itu diperlukan UV filter. Beberapa UV filter dalam tabir surya komersil menimbulkan dampak berbahaya. Oleh karena itu, diperlukan alternatif UV filter alami yang mengandung flavonoid, salah satunya adalah Daun Kamboja (Plumeria alba Linn.). Penelitian ini bertujuan untuk menguji kemampuan flavonoid sebagai UV filter secara in vitro dan in vivo. Ekstraksi dilakukan dengan maserasi menggunakan etanol $70 \%$ dan purifikasi flavonoid digunakan metode cair -cair. Parameter yang diukur adalah total kandungan flavonoid, nilai Sun Protector Factor [SPF], dan skoring gejala klinis penghambatan melanogenesis pada tikus. Rendemen hasil purifikasi sebesar 43,6\%. Kandungan flavonoid pada hasil purifikasi (64,4 mg QE/g), lebih tinggi dibanding ekstrak kasar $(57,6 \mathrm{mg}$ QE/g). Nilai SPF tertinggi $(33,88)$ ekstrak hasil purifikasi1400mg/mL, sedangkan pada konsentrasi yang sama ekstrak kasar menghasilkan nilai SPF yang lebih rendah $(33,06)$. Analisis data korelasi Pearson $(0,563)$ menunjukkan adanya hubungan positif yang berbanding lurus antara nilai SPF dan konsentrasi ekstrak. Pengujian in vivo dilakukan dengan skoring gejala klinis dimulai dari angka 0-4 berdasarkan tingkat keparahan eritema yang terjadi. Setelah 21 hari paparan sinar matahari, kelompok yang mengalami eritema terparah adalah kelompok kontrol negatif (skor 1,292), sedangkan hasil terbaik adalah kelompok perlakuan pengolesan ekstrak purifikasi $1400 \mathrm{mg} / \mathrm{mL}$ (skor 0,542).
\end{abstract}

Kata Kunci: flavonoid, Plumeria alba, skoring eritema, SPF, dan UV filter.

\section{ABSTRACT}

UV filters are necessary since UV rays are harmful to human skin. UV filter compounds in commercial sunscreen products can cause adverse effects. Thus, natural UV filters containing flavonoids, e.g. Frangipani (Plumeria alba Linn.) leaves, are needed. This research examined the use of flavonoids from P. alba leaf as a UV filter with in vitro and in vivo. Maceration was performed with $70 \%$ ethyl alcohol and liquid-liquid extraction for flavonoid purification. Parameters tested were total flavonoid compounds, SPF value, and clinical symptoms of the melanogenesis inhibition scoring. The purification result was $43.6 \%$. The flavonoid concentration in pure extract (64.4 $\mathrm{mg} \mathrm{QE} / \mathrm{g}$ ) was higher than crude extract $(57.6 \mathrm{mg}$ QE/g). The highest SPF value $(33.88)$ was observed in pure extract at $1400 \mathrm{mg} / \mathrm{mL}$, while the same concentration of crude extract resulted in a lower SPF value (33.06). Pearson correlation analysis (0.536) indicated a directly proportional relationship between SPF value and extract concentration. In vivo analysis was performed by scoring between $0-4$ following the severity of erythema. After 21 days of sunlight exposure, the worst erythema was found in the negative control group (score 1.292). The best result was found in the group treated with pure extract $1400 \mathrm{mg} / \mathrm{ml}$ (score 0.542 ).

Keywords: flavonoid, scoring erythema, Plumeria alba, SPF, and UV filter.

\section{INTRODUCTION}

Based on the wavelength, UV radiation can be divided into UVA (315-400 nm), UVB (280-320 $\mathrm{nm})$, and UVC (100-280 $\mathrm{nm})$. Among the three types of UV light, only UVA and UVB can penetrate through the Stratosphere. About $90-95 \%$ of incoming UV light is UVA which plays a role in the occurrence of "aging", while the rest is UVB which plays a role in occurrence of erythema and skin cancer (Dorazio et al., 2013; Tampucci, 2017). UVB rays are more harmful than UVA because it damages the skin directly (Naranayan et al., 2010). To avoid the adverse effects of UV radiation, skin protectors such as sunscreens are needed.

Sunscreens can absorb at least $85 \%$ of the sun rays at the wavelengths from 290 to $320 \mathrm{~nm}$ for UVB but wavelengths more than $320 \mathrm{~nm}$ for UVA are not absorbed (Suryanto, 2012 in Alhabsy et al., 2014). Based on their origin and capabilities, sunscreens are divided into organic UV filters (chemical) and inorganic UV filters (physical). Organic UV filters work by absorbing UV radiation then turning it into lower energy so that it does not cause sunburn effects on the skin, whereas inorganic UV filters work by reflecting or blocking UV rays (Lavi, 2012; Rosyidi et al., 2018). Benzophenone-3, avobenzone, methoxyicinamic, and andoctylsalicylate are used as organic UV filters (Rosyidi et al., 2018). Flavonoid scan counter act ultraviolet induction radicals (UV), by absorbing the UV rays. Some plants containing flavonoid and phenolic compounds have antioxidant benefits and are also known to be used as sunscreens (Fonseca, 2015; Pradika, 2016). 
Frangipani (Plumeria alba L.) is a plant containing flavonoids. Dawood et al. (2016) have shown that the leaf of $P$. alba contain flavonoids like quercetin and rutin which have been reported to act as UV filters (Choquenet et al., 2008; Marcos et al., 2016). Frangipani plants are widely distributed in Indonesia and can grow and reproduce without requiring special treatment (Wrasiati et al., 2011). Frangipani plants have multiple varieties, one of which is white frangipani (P. alba).

Frangipani leaf extract has been utilised as an anti bacterial against Staphylococcus aureus (Ningsih et al., 2014), P. alba flower essential oil as mosquito repellent aroma therapy (Nurcahyo and Purgiyanti, 2017), and $P$. alba flower extract as an anti-bacterial against $S$. aureus and Salmonella typhi (Rupianiasih et al., 2019). Based on several existing studies, the flower is the most commonly utilized component of the plant, while the leaves have seen little research. Seeing the potential of $P$. alba leaf, this study aimed to test the effective ness of flavonoids from Frangipani leaf extract as UV filters on the skin of Wistar rats that exposed to sunlight for 21 days.

\section{MATERIALS AND METHODS \\ Tools and materials}

Test tube, micropipette, blender, oven, rotary vacuum evaporator, UV-Vis Spectrophotometer, a set of surgical instruments (surgical scissors and scalpel), 100 mesh sieve, $250 \mathrm{~mL}$ separating funnel, water bath, and filter cloth.

Plumeria alba leaves were sampled from housing complexes around Kalasan, Sleman, Yogyakarta. The wet weight of $P$. alba leaf used was $7 \mathrm{~kg}$. Male Wistar rats aged 9 weeks weighing 150-200 g were used as test animals on in vivo SPF value testing, Aquadest, Aluminium chloride $\left(\mathrm{AlCl}_{3}\right) \quad 10 \%$, Ethanol 70\%, n-Hexane, Potassium Acetate $\left(\mathrm{CH}_{3} \mathrm{COOK}\right) 1 \mathrm{M}$, and methanol pro analyse (p.a).

\section{Sample preparation}

Plumeria alba leaves washed, removed the major veins, sliced $( \pm 1 \mathrm{~cm})$, and dried in an oven at $60^{\circ} \mathrm{C}$ for \pm 5 days. The dried leaves were then blended and sifted with a 100 mesh sieve. The resulting sample was stored in a plastic container with the addition of silica gel sachets to keep the sample in a dry state.

\section{Extraction}

Plumeria alba leaf extraction was carried out using a maceration method, with ethanol $70 \%$ as solvent. A total of $1.573 \mathrm{~g}$ dried $P$. alba was put into a glass jar and $70 \%$ ethanol was added until the powder was covered to a height of $3 \mathrm{~cm}$. The extraction process lasted for 5 days at $25^{\circ} \mathrm{C}$ with the jar closed, protected from sunlight, and stirred for the first 24 hours. The extract was filtered using filter cloth to separate liquid from the remaining leaf debris. The filtrate was then evaporated at $40^{\circ} \mathrm{C}$ for \pm 4 hours, until the extract became thick, to produce the crude extract.

\section{Purification extract}

Purification of the $P$. alba leaf extract was done to obtain the pure extract which contains flavonoids as target metabolic compounds. Purification was carried out by liquid-liquid extraction method based on Kusnadi and Devi (2017). A total of $50 \mathrm{~g}$ of crude extract was placed in separating funnels with $30 \mathrm{~mL} n$-hexane as the solvent, then shaking it until the two-phase separation occurred. The upper phase is the $n$-hexane solution with the non-polar compounds from the extract, while the lower phase contains the polar compounds in the extract such as flavonoids. The lower phase was then collected on a porcelain cup and evaporated in the water bath at $40^{\circ} \mathrm{C}$ until it thickened. This was then categorized as a pure extract.

\section{Determination of the quantity of flavonoid content}

Determination of the quantity of Flavonoid content in samples was based on a standard curve that uses pure quercetin as a standard solution. Standard solutions are made with ethanol $70 \%$ as solvent and concentrations of $40,50,60,70,80,90$, and 100 ppm quercetin. The concentration of Flavonoids was analyzed in both crude and pure extract. $1 \mathrm{~mL}$ of each sample was analyzed with the addition of $0.2 \mathrm{~mL}$ of $10 \% \mathrm{AlCl}_{3}, 0.2 \mathrm{M}$ of Potassium acetate, and adding up to $10 \mathrm{~mL}$ of distilled water. After 30 minutes, the absorbance of the sample was measured at a wavelength of $431 \mathrm{~nm}$.

\section{Determination of in vitro SPF value}

In vitro SPF measurements were carried out to test the effectiveness of $P$. alba leaf extract as a UV filter before being tested on animals (in vivo). SPF value measurements were carried out using a spectrophotometer at a wavelength of 290-340 nm with intervals of $5 \mathrm{~nm}$. The pure and crude extracts were first diluted in $70 \%$ ethanol solution to the concentration of $600 \mathrm{mg} / \mathrm{mL}, 800 \mathrm{mg} / \mathrm{ml}, 1000 \mathrm{mg} / \mathrm{ml}$, $1200 \mathrm{mg} / \mathrm{ml}$, and $1400 \mathrm{mg} / \mathrm{ml}$. The SPF value was determined using the Mansur et al. (1986) formulation (Sayre et al. (1979).

$* \mathrm{CF}=$ Correction Factor $(10), \mathrm{EE}=$ Erythemal Effect of Radiation, I = Solar Intensity Spectrum.

Determination of $\boldsymbol{P}$. alba leaf extract effectivity 
as a UV filter (in vivo testing)

In vivo testing was carried out to test the effectiveness of $P$. alba leaf extract as a UV filter by looking at the severity of the erythema experienced by testing animals. Ethical clearance (1174/C.16/FK/2020) was obtained prior to testing. The animals used were male wistar rats aged $8-12$ months. Test animals were randomly divided into three groups: positive control (group A), negative control (group B) and treatment group (group C). The negative control group only received the application of distilled water, 30 minutes before irradiation. The positive control group received the

$$
S P F=C F x_{320}^{290} \sum E E(\lambda) x I(\lambda) x \text { absorbance }(\lambda)
$$

application of commercial sunscreen with SPF 30, 30 minutes before irradiation. The treatment group received the application of $P$. alba leaf pure extract of $1400 \mathrm{mg} / \mathrm{ml}$. Each group of animals was exposed to sunlight for one hour (11.00-12.00 a.m.) WIB, for 21 days with observations every 3 days. Euthanasia of test animals was carried out on the $22^{\text {nd }}$ day. In vivo testing was done by assigning a score between 0 to 4 in which absence of erythema is scored 0 , erythema just visible is scored 1 , erythemaclearly demarcated is scored 2 , moderate to severe erythema is scored 3, and very sever erythema (red beets) with crust formation is scored 4. The final results of each group's scoring were averaged for all individuals and the highest score indicates the worst erythema.

\section{RESULTS \\ Extraction and purification}

A total of $1573 \mathrm{~g}$ sample of $P$. alba leaf with a moisture content of $22.5 \%$ were extracted by maceration methods using $70 \%$ ethanol as solvents for 5 days resulting the yield of $9.6 \%$ (Table 1). Based on the extraction result obtained, purification was carried out as the second stage of extraction to obtain the active compound of flavonoids. The solvent that used in the purification is $n$-hexane as much as $30 \mathrm{ml}$. Purification result from $90 \mathrm{~g}$ crude extract, produced $43.6 \%$ yield (table 2 ).

\section{Determination of flavonoid content}

Flavonoid analysis was carried out using quercetin as a standard solution, which is one of the flavonoids group that have the ability as UV protector (Marcos et al., 2017). The linear regression equation obtained was, $\mathrm{y}=0.0031 \mathrm{x}$ 0.0655 with a value of linearity $\left(\mathrm{R}^{2}\right), 0.9933$ which is close to 1 indicating that the correlation between sample concentration and sample absorbance is ideal. The results of quantitative determination of flavonoids show that the highest concentration in the pure extract was $64.4 \mathrm{mg} \mathrm{QE} / \mathrm{g}$, while in the crude extract was $57.6 \mathrm{mg}$ QE/g (table 3).

Table 1.The result of Flavonoid determination of $P$. alba leaf extract (Hasil pengukuran kadar Flavonoid dari ekstrak daun P. alba)

\begin{tabular}{|c|c|c|c|}
\hline $\begin{array}{c}\text { Sample } \\
\text { (sampel) }\end{array}$ & $\begin{array}{c}\text { Absorbance } \\
\text { (Absorbansi) (y) }\end{array}$ & $\begin{array}{c}\text { Mean absorbance } \\
\text { (Rata-rata absorbansi) } \\
\text { (y) }\end{array}$ & $\begin{array}{c}\text { Total Flavonoid Concentration } \\
\text { (Konsentrasi total Flavonoid) } \\
\text { (mgQE/g extract) }\end{array}$ \\
\hline $\begin{array}{l}\text { Crude extract } \\
\text { (Ekstrak kasar) }\end{array}$ & $\begin{array}{l}0.112 \\
0.110 \\
0.115\end{array}$ & 0.112 & 57.6 \\
\hline $\begin{array}{l}\text { Pure extract } \\
\text { (Ekstrak murni) }\end{array}$ & $\begin{array}{l}0.135 \\
0.133 \\
0.131\end{array}$ & 0.133 & 64.4 \\
\hline
\end{tabular}




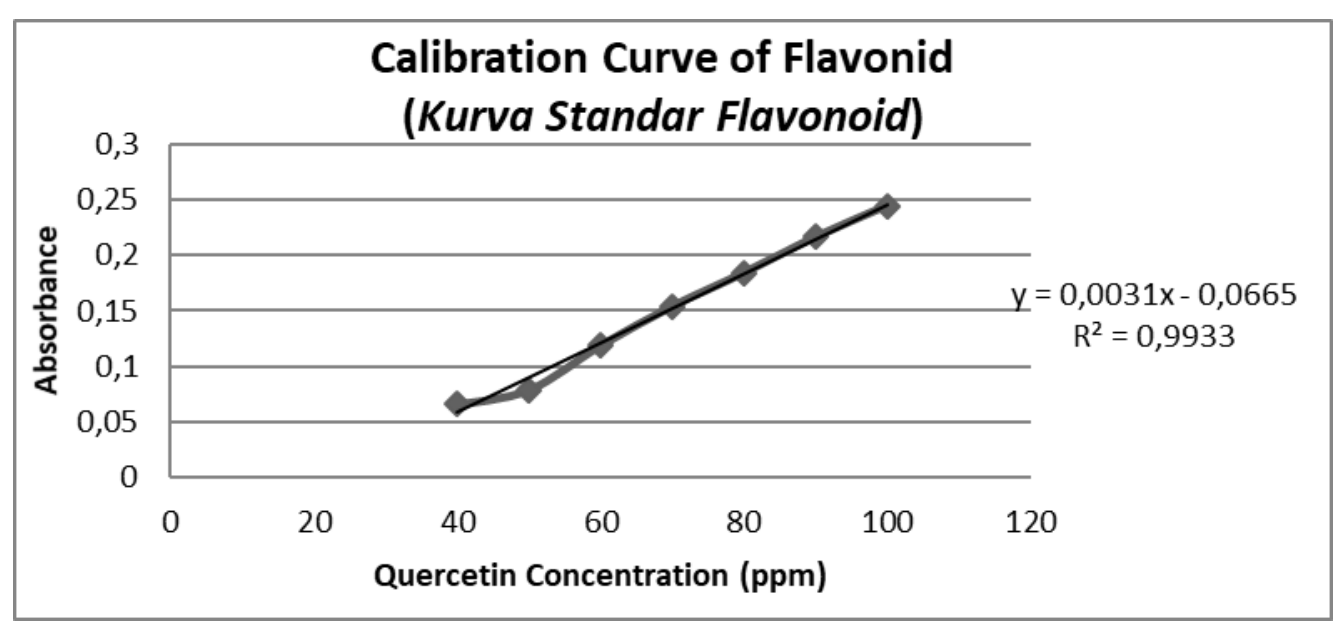

Figure 1. Calibration curve of quercetin in $431 \mathrm{~nm}$ wavelength (Kurva kalibrasi kuersetin pada panjang gelombang $431 \mathrm{~nm}$ )

\section{Determination of in vitro SPF value}

The SPF value was determined based on Mansur's (1986) equation, by measuring the absorbance at the wavelength of $290-320 \mathrm{~nm}$, at 5 $\mathrm{nm}$ interval (Sayre et al., 1979). The highest SPF value was obtained in pure extract of $1400 \mathrm{mg} / \mathrm{mL}$, which was 33.88. Extract concentration and SPF value showed a positive correlation both in the crude extract and pure extract as evidenced by the
Pearson correlation value of $0.563\left(\mathrm{p}<0.01, \mathrm{R}^{2}\right.$ 0.961 , Table 4). Pearson's correlation is considered strong between 0.40 to 0.599 (Kirom, (2015) in Rufaidah et al., (2019)). The $\mathrm{R}$ squared $\left(\mathrm{R}^{2}\right)$ value of 0.961 means that $96.1 \%$ of the SPF value is influenced by differences in concentration and type of extracts, while the $3.9 \%$ of the SPF value is influenced by other factors.

Table 2.The result determination of in vitro SPF value from $P$. alba leaf extract (Hasil Pengujian nilai SPF secara in vitro dariekstrak P. alba).

\begin{tabular}{lcccc}
\hline No & $\begin{array}{c}\text { Concentration } \\
(\mathbf{m g} / \mathbf{m l})\end{array}$ & \multicolumn{2}{c}{ SPF value } & Sunscreen \\
\cline { 3 - 4 } & & $\begin{array}{c}\text { Crude extract } \\
(\mathbf{C E})\end{array}$ & $\begin{array}{c}\text { Pure extract } \\
(\mathbf{P E})\end{array}$ & \\
\hline 1 & 600 & 8.00 & 8.42 & Extra \\
2 & 800 & 14.16 & 17.99 & Maximal \\
3 & 1000 & 16.15 & 18.44 & Ultra \\
4 & 1200 & 26.37 & 27.43 & Ultra \\
5 & 1400 & 33.06 & 33.88 & Ultra \\
\hline \multicolumn{2}{l}{ Pearson Correlation } & & 0.563 & \\
\hline \multicolumn{2}{l}{ Sig } & & 0.000 & \\
\hline \multicolumn{2}{l}{ R square $\left(\mathbf{R}^{2}\right)$} & & 0.961 & \\
\hline
\end{tabular}

\section{Comparison between Flavonoid Concentration towards SPF Values}

Comparison between extract concentration, flavonoid concentration and SPF value is directly proportional where the higher the extract concentra- tion, the higher the flavonoid content and it also increases the SPF value. Regression value $\left(\mathrm{R}^{2}\right)$ obtained shows a good level of confidence because it is close to 1 (Figure 2 and 3). 
Table 3. Relationship of flavonoid extract concentration and SPF value (Hubungan antara konsentrasi flavonoid dalam ekstrak dan nilai SPF)

\begin{tabular}{ccccc}
\hline \multirow{2}{*}{$\begin{array}{c}\text { [Extract] } \\
\text { [Ekstrak] } \\
(\mathbf{m g} / \mathbf{m L})\end{array}$} & \multicolumn{2}{c}{$\begin{array}{c}\text { Crude extract } \mathbf{( C E )} \\
\text { (ekstrakkasar) }\end{array}$} & \multicolumn{2}{c}{$\begin{array}{c}\text { Pure extract }(\mathbf{P E}) \\
\text { (ekstrakmurni) }\end{array}$} \\
\cline { 2 - 5 } & $\begin{array}{c}\text { [Flavonoid] } \\
(\mathbf{m g})\end{array}$ & SPF value & $\begin{array}{c}\text { [Flavonoid] } \\
(\mathbf{m g})\end{array}$ & SPF value \\
\hline 600 & 34.56 & 8.00 & 38.64 & 8.42 \\
800 & 46.08 & 14.16 & 51.52 & 17.99 \\
1000 & 57.6 & 16.15 & 64.4 & 18.44 \\
1200 & 69.12 & 26.37 & 77.28 & 27.43 \\
1400 & 80.64 & 33.06 & 90.16 & 33.88 \\
\hline
\end{tabular}

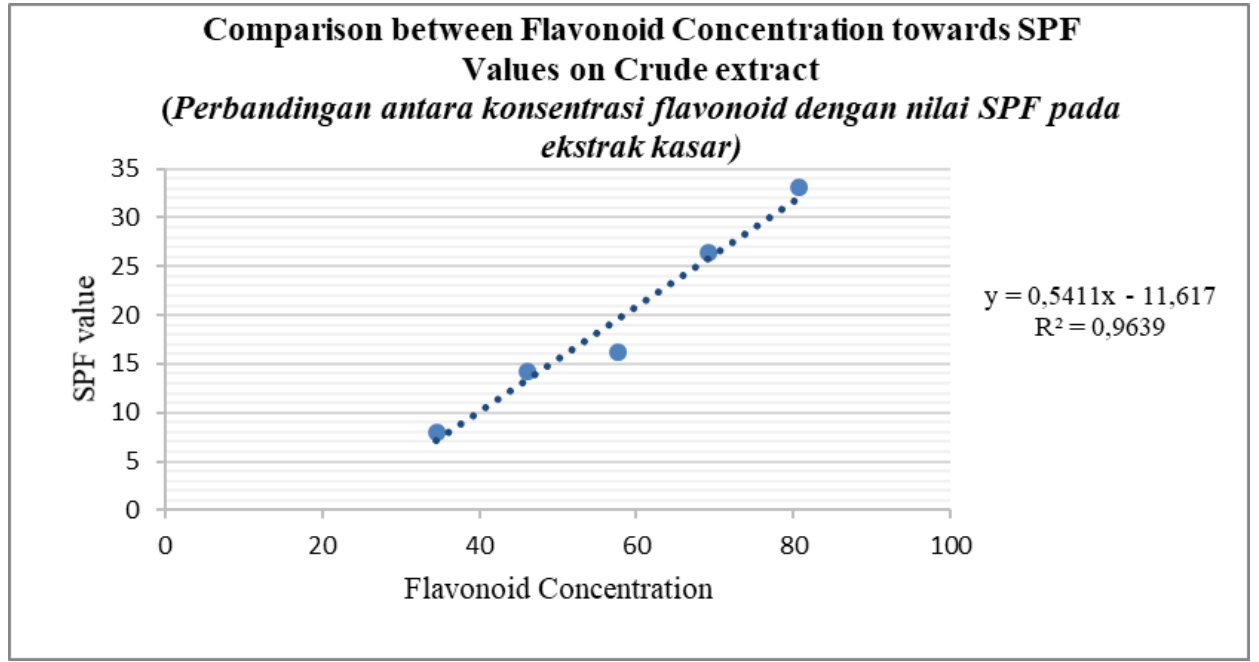

Figure 2. Relationship of Flavonoid concentration and SPF value in Crude extract (Hubungan antara konsentrasi Flavonoid dan nilai SPF pada sampel ekstrak kasar)

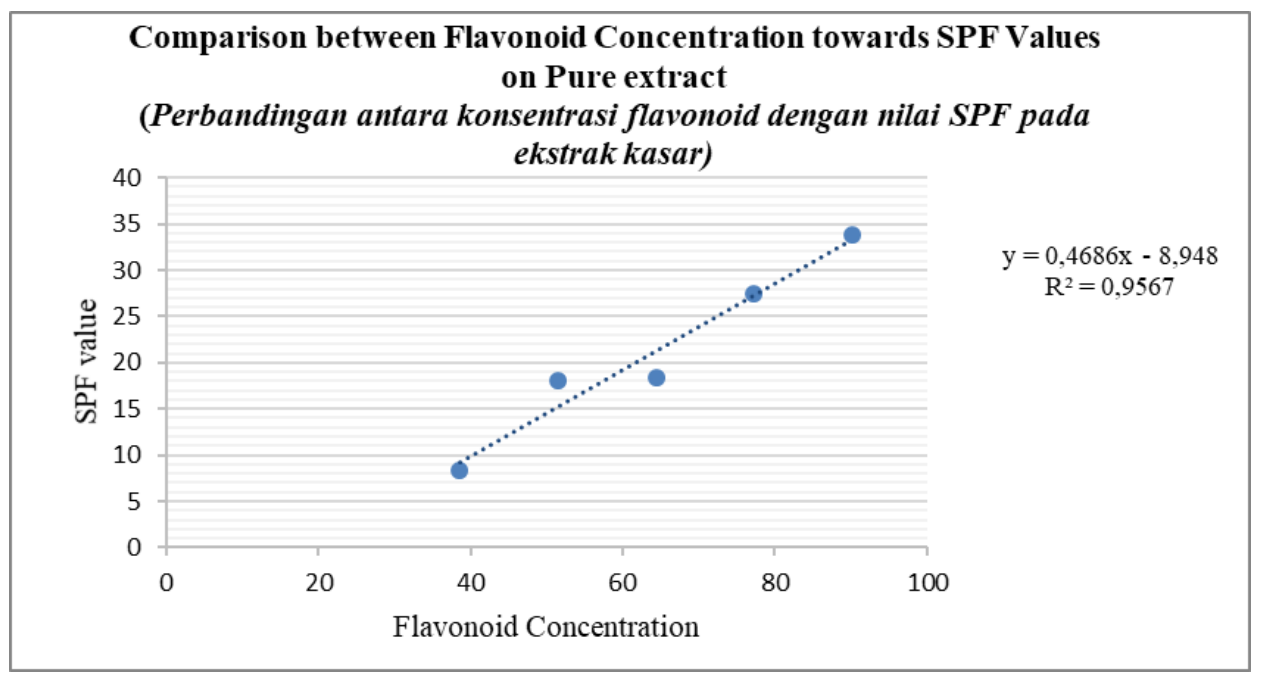

Figure 3. Relationship of Flavonoid concentration and SPF value in pure extract (Hubungan antara konsentrasi Flavonoid dan nilai SPF pada ekstrak murni). 


\section{Determination of $P$. alba leaf extract effectivity as a UV filter (in vivo Testing)}

Statistical analysis (Annova, $\mathrm{R}^{2} 0.964, \mathrm{p}=0.023$ ) indicates that there is a significant effect of treatment on the severity of erythema in the test animals' skin. The best results are observed in the test group animals which received the application of pure extract of $1400 \mathrm{mg} / \mathrm{mL}$ with the lowest average erythema score $(0.542)$, while the largest erythema score (1.292) was in the negative group of test animals which only received distilled water treatment (Table 6).

Table 4. Average scoring of in vivo testing result on white rats (Rattus novergicus) [Skoring rerata hasil pengujian in vivo pada tikus putih (Rattus novergicus)].

\begin{tabular}{cccc}
\hline \multirow{2}{*}{$\begin{array}{c}\text { Days } \\
\text { (Hari) }\end{array}$} & Group A & Group of Rat (Kelompoktikus) & Group C \\
\cline { 2 - 4 } & 0.000 & 0.000 & 0.000 \\
3 & 0.000 & 0.000 & 0.000 \\
6 & $0.667 \pm 0.58$ & 0.000 & $0.667 \pm 1.16$ \\
9 & $1.333 \pm 0.58$ & $0.667 \pm 1.16$ & $0.667 \pm 1.16$ \\
12 & $1.667 \pm 0.58$ & $1.667 \pm 0.58$ & 0.000 \\
15 & $1.333 \pm 1.16$ & $1.333 \pm 1.16$ & $0.667 \pm 1.16$ \\
18 & $2.333 \pm 0.58$ & $1.333 \pm 0.58$ & $1.333 \pm 0.58$ \\
21 & $3 \pm 0.000$ & $1.333 \pm 0.56$ & $0.542 \pm 0.57$ \\
\hline Mean & $1.292 \pm 0.41$ & $0.792 \pm 0.48$ & $\mathbf{0 . 0 2 3}$ \\
\hline Sig & \multicolumn{4}{c}{$\mathbf{0 . 9 6 4}$} \\
\hline R square $\left(\mathbf{R}^{\mathbf{2}}\right)$ & \multicolumn{4}{c}{}
\end{tabular}

\section{DISCUSSION}

A previous study showed that flavonoid extraction from $200 \mathrm{~g}$ of $P$. alba leaf using 70\% ethanol as a solvent, and shaken at $120 \mathrm{rpm}$ for 7 days, produced a yield of $6 \%$ of dry weight (Ningsih et al., 2014). Ethanol is effective to extract active flavonoids which are polar because they have unsubstituted hydroxyl groups (Kemit et al., 2017). Ethanol 70\% was chosen because based on previous researches, it was able to produce the highest yield of flavonoid extraction from the rhizome thatch compared with concentrations of $60 \%, 80 \%$, and $90 \%$ (Arifin et al., 2006); Suhendra et al., 2019)). The difference between studies conducted by Ningsih et al., 2014), and this research, indicates that the contact time between sample and solvent effects the yield obtained. The maceration process using a shaker is more optimal than the extraction process with manual stirring. The initial extract from the extraction process is assumed to still have many other active compounds besides flavonoids, so it is called crude extract (CE).
The crude extract wasthen extracted again through a purification process to get the active flavonoid compounds. Purification was carried out as a second stage of extraction to obtain the flavonoid compounds. The method used in the purification process was liquid-liquid method using separating funnel, based on the process of extracting flavonoids in celery leaf by Kusnadi and Devi (2017). Purification was carried out based on the 'like dissolve like' principles, where the nonpolar $n$-hexane solvents will attract the non-polar compounds and two phases will be formed in the separating funnel after shaking out (Figure 4). The upper phase is an $n$-hexane solvent with other nonpolar compounds which are still contained in the extract, while the lower phase is a polar compound such as flavonoids (Kusnadi and Devi, 2017). The purification yield is called the pure extract. 


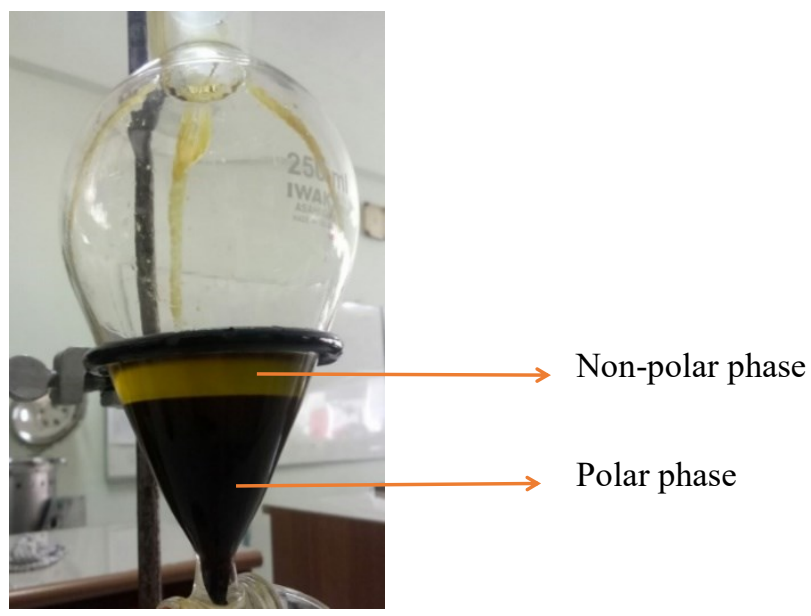

Figure 4. Purification process of Plumeria alba leaf extract (Proses purifikasi dari ekstrak daun Plumeria alba)

The resulting flavonoid content in pure extract was higher than in the crude extract (Table 3). This showed that flavonoid isolation carried out had separated the flavonoids from other remaining nonpolar compounds in the crude extract. Previous studies of flavonoid concentration in frangipani $(P$. $a l b a$ ) leaf have been carried out by Dawood et al. (2016), using methanol as a solvent, with a final flavonoid concentration of $74.7 \mathrm{mg} \mathrm{QE} / \mathrm{g}$. The difference in this result is possibly due to the different solvent that was used. The higher flavonoid content in the pure extract compared to crude extract was also supported by the SPF value that higher in the pure extract (Table 5). The concentration of extract was shown to have a significant and positive linear relationship with the SPF value evidenced by the positive Pearson correlation value and $p<0.001$. he highest SPF value was found in the pure extract with the concentration of $1400 \mathrm{mg} / \mathrm{mL}$ (SPF 33.88). Based on the categorisation of sunscreen according to the Food and Drug Administration, The SPF value of 33.88 is in ultra-protection category which indicates that the pure extract of $1400 \mathrm{mg} / \mathrm{mL}$ has a high ability to protect against UV rays (Ismail et al., 2014). The higher the concentration of the extract used, the higher the concentration of flavonoid it contains. This increases the ability of the extract to function as a UV filter as evidenced by an increase in the SPF value (Table 4). The concentration with the highest SPF value (pure extract, $1400 \mathrm{mg} / \mathrm{mL}$ ) was used in in vivo testing to determine its effectiveness against erythema prevention.

In vivo testing used male Rattus novergicus of the age 8-12 months, to avoid other effects such as the estrogen hormone which plays a role in increasing the amount of melanin in cells and the progesterone hormone which can increase the spread of melanin in cells (Muller and Rees, 2014). The test was carried out by exposing the rats to the sun for 1 hour per day (11.00 to 12.00 WIB) for 21 days. The treatment was divided into 3 groups namely the positive group which received commercial sunscreen before exposure, the negative group only received distilled water before exposure and the treatment group which received PE extract with a concentration of $1400 \mathrm{mg} / \mathrm{mL}$, which had the best SPF value. The application process was carried out 30 minutes before exposure. Observation of test animals was done every 3 days based on the statement of Baumanand Saghari (2009) that pigmentation begins 2-3 days after exposure.

The results revealed that the application of pure extract with a concentration of $1400 \mathrm{mg} / \mathrm{mL}$ (group C) produced the lowest score $(0.542)$, followed by the positive control group (group B) that received commercial sunscreen (0.792), and the highest was the negative control group (group C) (1.292). The deviation score between the positive control group and the negative control group was 0.25 which was not very large. It is suggested that the lower scoring of erythema in thetreated rat group compared to the positive control was due to the higher SPF value in the extract. In other ways, the extract's color which is black-green also affecting the result, supported by Wilson et al. (2018), where dark color such as dark green, red, dark blue and black providing good protection through UV rays, while the darker shades have been associated with the higher UV protection value.

The appearance of rat skin from the positive control group and the treatment group immediately and 30 minutes after application can be seen in Figures 5 and 6 . The red circle indicates the application area. 


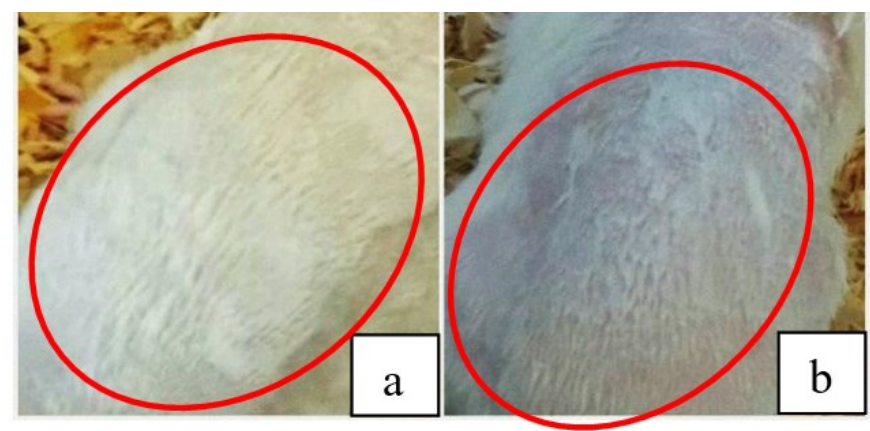

Figure 5. Positive control group (a) afterthe basting of comercial sunscreen (b) 30 minutes after the basting [Kelompok kontrol positif (a) setelah pengolesan tabir surya komersil (b) 30 menit setelah pengolesan]

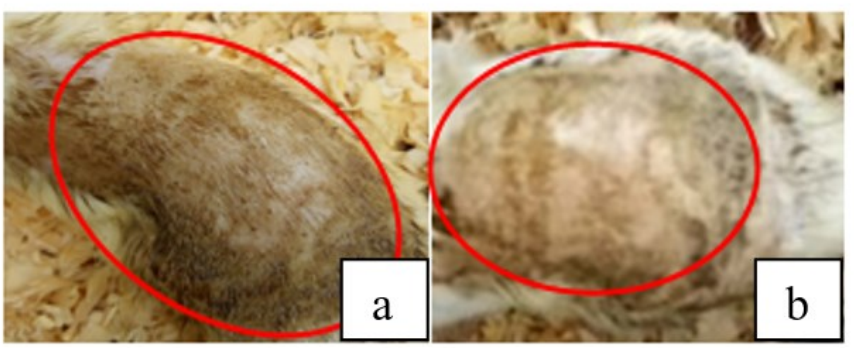

Figure 6. Treatment group (a) after the basting of Pure extract $1400 \mathrm{mg} / \mathrm{mL}$ (b) 30 minutes after the basting [Kelompok perlakuan (a) setelah dioles ekstrak murni $1400 \mathrm{mg} / \mathrm{mL}$ (b) 30 menit setelah pengolesan]

The results of the average erythema scoring value obtained an $R$ square $\left(R^{2}\right)$ value of 0.964 which showed that $96.4 \%$ of erythema observed on the skin of test animals was influenced by differences in treatment while the rest $(3.6 \%)$ was influenced by factors other than differences in the treatment. Some of these factors include the behavior of the rats to lie over each other when exposed to sunlight which causes differences in scores between mice within a group. Weather also had a large effect on the fluctuation of three daily erythema scoring of the rats. Fluctuation in the score at each observation day indicates that UV filter testing with in vivo method using sun exposure is less effective. Documentation of the appearance of rat's back skin before sun exposure can be seen in Figure 3 and the appearance of rat's back skin after 21 days of exposure can be seen in Figure 4 , where the erythema is marked by a red circle.
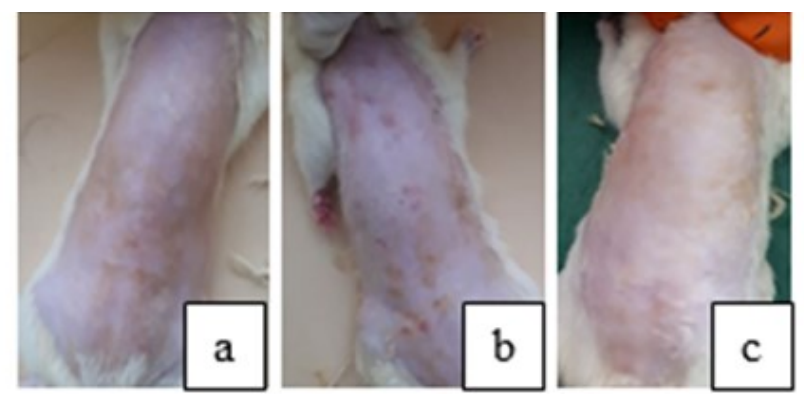

Figure 7. Rat's skin on the first day before sun exposure $\left(\mathrm{H}_{0}\right)$ (a) Group of negative control (b) Group of positive control (c) Treatment group [Kulit tikus sebelum dipapar matahari $\left(H_{0}\right)$ (a) Kelompok kontrol negatif (b) Kelompok kontrol positif (c) Kelompok perlakuan]. 


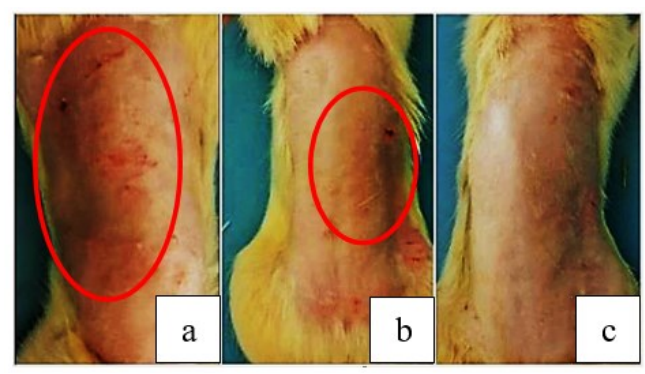

Figure 8. Rat's skin on the $21^{\text {th }}$ day after sun exposure $\left(\mathrm{H}_{21}\right)$ (a) Group of negative control (1.242) (b) Group of positive control (0.792) (c) Treatment group (0.542) (Kulit tikus setelah 21 hari pemaparan $\left(H_{21}\right)$ (a) Kelompok control negatif (1.242) (b) Kelompok kontrol positif (0.792) (c) Kelompok perlakuan (0.542)).

\section{CONCLUSION}

Based on the test results of $P$. alba leaf, it is shown that the leaves of $P$. alba have the ability to act as UV filters due to their flavonoid content. The measurement of flavonoid content in crude extract was $57.6 \mathrm{mg} \mathrm{QE} / \mathrm{g}$, while in pure extract was 64.4 $\mathrm{mg} \mathrm{QE} / \mathrm{g}$. The results of pure extract testing at a concentration of $1400 \mathrm{mg} / \mathrm{mL}$ showed the best ability as a UV filter seen from the highest SPF value of 33.88. Application of pure extract with a concentration of $1400 \mathrm{mg} / \mathrm{mL}$ provides the best results in reducing erythema with a scoring result mean of 0.542 , which indicates less erythema on the skin.

\section{ACKNOWLEDGEMENTS}

This research was held in Faculty of Biotechnology, Duta Wacana Christian University. I would like to express my gratefulness to Dra. Aniek Prasetyaningsih, M. Siand drh. Vinsa Cantya Prakasita, S.K.H, M.Sc as my supervisor for their warm support, inspiration and thoughful guidance. Without their contribution this research won't be finished.

\section{REFERENCES}

Alhabsy, D.F., Suryanto, E. dan Wewengkang, D.F., 2014 Aktivitas antioksidan dan tabir surya pada ekstrak kulit buah Pisang Goroho (Musa acuminate L.). Jurnal Ilmiah Farmasi, 3(2), pp.107-114.

Arifin, H., Anggraini, N., Handayani, D. dan Rasyid, R., 2006. Standarisasi ekstrak etanol daun Eugenia cumini Merr. Jurnal Sains Tek. Farmasi, 11(2), pp.88-93.

Choquenet, B., Couteau, C., Paparis, E. and Coiffard, L.J.M., 2008. Quercetin and rutin as potential sunscreen agents: Determination of efficacy by an in Vitro method. Journal of Natural Products, 71(6), pp.1117-1118.

Dawood, D., Hassan, R. and Abdelfattah, S. 2016., Antioxidant activity evaluation of methanolic extract and crude polysaccharides from Plumeria alba L. leaves. International Journal of Advanced Research, 4, pp.16881701.

Dorazio, J., Jarrett, S., Amaro-Ortiz, A. and Scott, T., 2013. UV radiation and the skin. International Journal of Molecular Sciences, 14(6), pp.12222-12248.
Ismail, I., Handayany, GH., Wahyuni, D. dan Juliandri., 2014. Formulasi dan penentuan nilai SPF (Sun Protecting Factor) sediaan krim tabir surya ekstrak etanol daun kemangi (Ocimum sanctum L.). JF FIK UINAM, 2(1), pp.6-11.

Kemit, N., Rai, Widarta, I.W, dan Nocianitri, K.A., 2017. Pengaruh jenis pelarut dan waktu maserasi terhadap kandungan senyawa flavonoid dan aktivitas antioksi dan ekstrak daun alpukat (Persea americana Mill.). Jurnal Ilmu dan Teknologi Pangan (ITEPA), 5(2), pp.130-141.

Kumoro, A.C., Hasan, M, and Singh, H., 2009. Effect of solvent properties on the soxhlet extraction of diterpenoid lactones from Andrographis paniculate leaves. Science Asia, 35, pp. 306-309.

Kusnadi, K. dan Devi, E.T., 2017. Isolasi dan identifikasi senyawa flavonoid pada ekstrak daun seledri (Apium graceolens L.) dengan metode refluks. Pancasakti Science Education Journal, 2(1), pp.56-67.

Lavi, N., 2013. Tabir Surya Bagi Pelaku Wisata. Denpasar: Universitas Udayana.

Mambro, V.M.D. and Fonseca, M.J.V., 2005. Assays of physical stability and antioxidant activity of a topical formulation added with different plant extracts. Journal of Pharmacentical and Biomedical Analysis, 37(2), pp. 287-295.

Marcos, T.D.M.J., Pedrita, A.S., Emanuella, C.V.P., Raimundo, G.D.O.J., Fabrício, S.S., Roberto, G.D.A.J., Rolim, L.A., Nunes, X.P. and Edigênia, C.D.C.A., 2016. Flavonoids as photoprotective agents: A systematic review. Journal of Medicinal Plants Research, 10(47), pp.848-864.

Muller, I.and A. Rees., 2014. Melasma and endocrine disorders. Journal of Pigmentary Disorders. doi: 10.4172/JPD.S1001.

Ningsih, D.R., Zusfahair, dan Purwati., 2014. Potensi ekstrak daun kamboja (Plumeria alba $\mathrm{L}$.) sebagai antibakteri dan identifikasi golongan senyawa bioaktifnya. Jurnal Molekul, 9(2), pp.101-109.

Nurcahyo, H. dan Purgiyanti., 2017. Pemanfaatan bunga kamboja (Plumeria alba) sebagai aromaterapi pengusir nyamuk. Jurnal Para Pemikir, 6(1), pp.121-123.

Pradika, Y., 2016. Uji ektivitas Tabir surya ekstrak batang pisang Ambon (Musa paradisiaka var. sapientum) [SKRIPSI]. Universitas Islam Negeri Sunan Kalijaga, Yogyakarta.

Rosyidi, V.A., Deni, W. dan Ameliana, L., 2018. Optimasi titanium dioksida dan asam glikolat dalam krim tabir surya kombinasi benzofenon-3 dan oktil metoksisinamat. Pharmaceutical Journal of Indonesia, 15(1), pp. 60-71.

Rufaidah, V., Erwina, W. dan Yanto, A., 2019. Hubungan kualitas web kandaga terhadap kebutuhan informasi Pengguna. Jurnal Ilmu Perpustakaan dan Informasi, 4(1), 
pp. 31-40.

Rupiniasih, N.N., Indriani., Syamsuddin, dan Razak, A.R., 2019. Aktivitas antibakteri fraksi $n$-Heksan, kloroform, etil asetat bunga kamboja (Plumeria alba) terhadap bakteri Staphylococcus aureus dan Salmonella typhi. Jurnal Kovalen, 5(2), pp.173-181.

Sayre, R.M., Agin, P.P., Levee, G.J. and Marlowe, E., 1979. A comparison of in vivo and in vitro testing of sunscreening formulas. Photochemistry and Photobiology, 29(3), pp.559-566.

Suhendra, C.P..Widarta, I.W.R. dan Wiadnyani, A.A.I.S., 2019.

Pengaruh konsentrasi etanol terhadap aktivitas antioksidan ekstra krim pangilalang (Imperata cylindrica (L.)
Beauv.) Pada ekstraksi menggunakan gelombang ultrasonic. Jurnal Ilmu dan Teknologi Pangan, 8(1), pp.27-35.

Tampucci, S., Burgalassi, S., Chetoni, P. and Monti, D., 2017.

Cutaneous permeation and penetration of sunscreens: Formulation strategies and in vitro methods. Cosmetics, 5 (1), pp.1-17.

Wilson, C.A., Gies, P.H., Niven, B.E., McLennan, A. and Bevin, N.K., 2008. The relationship between UV Transmittance and color-visual description and instrumental Measurement. Textile Research Journal, 78(2), pp.128137. 